\title{
HAPPY DRAGON IS REAL, FRIGHTENING DRAGON IS NOT: CHILDREN'S FANTASY-REALITY DISTINCTION OF EMOTIONAL STIMULI
}

\author{
Sanja METLIČAR \\ Department of Psychology, Faculty of Arts, University of Ljubljana \\ Aškerčeva 2, 1000 Ljubljana, Slovenia \\ E-mail: sanja.metlicar@yahoo.com
}

\begin{abstract}
The focus of the study was fantasy-reality distinction of emotional stimuli in early childhood. Several factors were examined, including age differences, children's wishes, and local context. The research was conducted on a sample of 71 three to five-year-olds. Children were shown images depicting fantastic and real events and figures that elicited several emotions. They then reported whether each event or figure could occur in real life, stated their wishes regarding its occurrence in real life, and rated their emotional reaction to the image. Results revealed agerelated improvements in children's fantasy-reality distinction and positive correlations between children's reality status evaluations and their wishes, as well as variations in judgment based on emotional content of presented stimuli. Children were more likely to report that neutral and happy stimuli could occur in real life and that frightening and angry stimuli could not occur in real life.
\end{abstract}

Key words: early childhood, fantasy-reality distinction, emotion

Results from a wide range of studies seem to imply that there are many factors influencing children's ability to differentiate between fantasy and reality, e.g. age (Morison, Gardner, 1978), contextual stimuli (Wooley, Van Reet, 2006), emotional content (Carrick, Quas, 2006), individual differences (Bourchier, Davis, 2000a), etc. According to Samuels and Taylor (1994), the difficulties children experience in fantasy-reality distinction arise in situations where fantasy objects, events and beings a) are not explicitly specified as such and b) are emotionally charged. In fairy tales, cartoons, and during symbolic play children encounter these kinds of situations on a daily basis. Therefore, it is important that we gain better understanding of the limits and mechanisms underlying their fantasy-reality judgments.
At first glance, the results gained in this field of empirical research seem contradictory. Whilst some authors report that even in early childhood children are capable at discerning real entities from fantasy/mental entities (e.g., Weisberg, Sobel, 2012; Woolley, Wellman, 1992), others claim that fantasyreality confusion persists into middle childhood (e.g., Boerger, 2011; Bourchier, Davis, 2000 b). It would be difficult to pinpoint the exact moment when children begin to understand the difference between fantasy and reality because of the continuous nature of the process of change (Woolley, Tullos, 2009). There seems to be a growing support for the claim that young children indeed understand the difference between fantasy and reality under certain conditions but they are not always able to maintain the boundary

DOI: $10.21909 /$ sp.2014.02.657 
between them. Samuels and Taylor (1994) suggest that the variation in children's ability to discern fantasy and reality might be related to the way the fantasy-reality distinction is instantiated.

Support for their proposal comes from a study conducted by Sharon and Woolley (2004), the results of which show a contrast between children's inaccurate fantasy-reality judgments and their accurate property attributions. This contrast leads the authors to consider the existence of an implicit category in the minds of preschoolers, in which they place those entities they do not yet label as pretend, but to which they attribute few human-like properties. By gaining new information about the world, the contrast between properties of the real entities and those of fantasy entities increases, which might help children at fantasy-reality distinction. The study showed that children successfully differentiate between real and fantasy entities in their attributions of properties (e.g., physical, social) before they are capable of successfully judging whether those entities belong to the 'real' or 'pretend' category.

Another field of research alerting to the fact that children are not always able to maintain the fantasy-reality boundary is the research on fantasy-reality confusion in emotionally charged situations. In their article, Samuels and Taylor (1994) described a study they conducted to explore preschoolers' ability to distinguish real and fantasy stimuli of different emotional charge. Participants were tested individually and were randomly assigned to either emotion or neutral condition. Children in the emotion condition were presented with real and fantasy pictures depicting frightening situations, while children in the neutral condition were shown real and fantasy pictures of neutral situations. Each picture was followed by several questions, including whether the depicted event could occur in real life. Samuels and Taylor (1994) concluded that children were more successful in distinguishing real events from fantasy events when faced with neutral stimuli. When faced with frightening stimuli children were prone to a) correctly report that fantasy events depicted in the pictures could not occur in real life, and b) incorrectly report that real events depicted in the pictures could not occur in real life.

The idea of exploring preschoolers' ability to discriminate emotional fantasy and reality using pictorial stimuli was further developed by Carrick and Quas (2006). The authors pointed out the necessity of direct comparison of children's fantasy-reality distinction for several different emotions, because discrete emotions differ significantly in valence and motivation. Whilst fear is determined by negative valence and usually elicits avoidance of the frightening stimuli (Wacker, Heldmann, Stemmler, 2003), happiness is related to positive valence and approach response (Carver, White, 1994). Anger, however, while negatively valenced (Wacker et al., 2003) can elicit either approach or avoidance of the presented stimuli (Carrick, Quas, 2006). To explore children's fantasy-reality differentiation of stimuli with different emotional charge, Carrick and Quas (2006) presented 128 three to five-year-olds with pictures depicting real and fantasy events that elicited several emotional responses: happiness, fear, anger and neutral. Among other things, authors measured the intensity of child's emotional response to the pictures. The results showed a clear bias in children's reality status judgments: regardless of the actual fan- 
tasy-reality status of presented stimuli, they were more likely to claim that events depicting neutral or positive emotions could occur in real life and that events depicting negative emotions could not. Furthermore, this pattern of responses was especially prominent amongst preschoolers who reported stronger emotional reactions to the images. Interestingly, emotional valence affected children's reality status judgments across age. Whilst older children were better able to distinguish fantasy and reality, their responses were affected by emotional content of the presented stimuli in the same way as were those of younger children.

Similar results were later obtained in a study by Carrick, Quas and Lyon (2010), which focused on a comparison of maltreated and non-maltreated children's evaluations of emotional fantasy while using the same empirical procedures. The study showed that the response pattern of maltreated children differed significantly from that of the nonmaltreated children, in that maltreated children were prone to correctly state that negative real events could occur in real life but also to incorrectly state that negative fantasy events could occur in real life. The authors proposed that the response pattern witnessed in maltreated children could at least in part be a reflection of their experiences, based on which they know that negative events can and do occur in real life.

Several explanations have been proposed as to why normative children, when faced with fantasy-reality distinction of emotional stimuli, respond in a pattern described by Carrick and Quas (2006) and by Samuels and Taylor (1994). According to Carrick and Quas (2006) important factors to consider include approach/avoidance tendencies and emotion regulation strategies. It is possible that when faced with frightening events children use their response to the question Could this happen in real life? as an attempt to regulate their own emotional reaction (Samuels, Taylor, 1994) by detaching themselves from the presented stimuli (Carrick, Quas, 2006). Similarly, when faced with happy events they try to use their response to the aforementioned question as a way to intensify their positive emotional response. They do this by engaging with positive events: they state that the events could occur in reality regardless of their actual fantasy-reality status (Carrick, Quas, 2006).

Another possible explanation for the bias in children's reality status judgments of emotional stimuli is that the participants' responses are driven by their wishes instead of their actual understanding of the differences between fantasy and reality (Carrick, Quas, 2006). While adults understand that a person's thoughts only influence reality indirectly, i.e. through his or her actions (Woolley et al., 1999), children might claim that imaginary objects exist in reality because that is what they hope or wish for and because they are not sure whether simply imagining something can cause it to occur in real life (Woolley, 1997). It is possible, therefore, that in studies of fantasy-reality distinction of emotional stimuli children's judgments reflect their wish that positive events would and negative events would not occur in reality (Carrick, Quas, 2006). Woolley et al. (1999) report that a reduction in children's beliefs about the efficacy of wishing can be observed between the ages of three and six. This is when there seems to be an observable shift from direct to indirect causality between people's minds and the world, which means that in preschool years children 
slowly start to realize that wish by itself cannot cause changes in physical world.

Besides the method with which reality status judgments are instantiated and the emotional content of the presented stimuli, local context might also influence children's fantasy-reality distinction. Local context can be defined as what directly surrounds a specific element, for example, words or sentences that surround a novel word in written texts (Woolley, Van Reet, 2006) or images surrounding specific visual stimuli. There is a notable lack of data, concerning the effect the type of pictorial stimuli has on children's fantasy-reality distinction. Based on reports by Woolley and Van Reet (2006), who claim that even in preschool years children are able to use context to make reality status judgments about novel entities, one might assume that children's judgments would be more accurate when faced with visual stimuli of events rather than entities. The reason for that assumption is the fact that the figures in the pictures depicting events are set in a certain local context. This context might help children to decide which fantasy-reality status category to place them in. However, Samuels and Taylor (1994) claim that fantasyreality confusion is especially prevalent when children are asked to categorize events instead of single objects. While the authors do not offer explanation for their claim, it might be due to the conflicting information children receive while looking at a picture depicting fantasy events. For example, while looking at an image of a clothed duck swimming in a pond and smoking a pipe, children might correctly assume that the clothed duck is a fantastic figure and that a duck smoking is a fantastic event. There is, however, other information contained within that image. There is a pond (these exist in reality) and the duck is swimming in it (ducks do swim in ponds in real life). It is possible that many types of (often contradictory) information present in visual stimuli depicting events cause children to become confused as to the fantasy-reality status of said stimuli.

There are many more potentially important factors influencing preschoolers' fantasyreality distinction, of which age is the most relevant for the present study. Age-related differences in fantasy-reality differentiation have been reported by numerous researchers (e.g., Harris et al., 1991; Samuels, Taylor, 1994; Woolley, Tullos, 2009). During preschool years, children gradually develop the ability to discriminate fantasy and reality (Golomb, Galasso, 1995) by gaining and using new information about these worlds (Phelps, Woolley, 1994). Their experiences are important in preventing fantasy-reality confusion (Cook, Sobel, 2011) and with age they grow increasingly aware of the reality status of entities which they encounter (Sayfan, Hansen Lagattuta, 2009).

The present study aims to explore the relationship between emotion and children's ability to discriminate between fantasy and reality. To achieve this goal, a procedure similar to that of Carrick and Quas (2006) was used. However, there were two notable differences. First, the procedure of the aforementioned authors did not allow the comparison of children's reality status evaluations of events and their reality status evaluations of entities. And second, gathering data on children's wishes about the reality status of presented stimuli was not a part of the original procedure. Therefore, to explore the role of local context and children's wishes in fantasy reality distinction, there were two types of pictorial stimuli - pictures depicting events and pictures depicting entities - 
as well as a measurement of children's reality status wishes used in the present study.

We postulated four hypotheses. First, age-related improvement in children's fantasy-reality distinction was expected (e.g., Carrick, Quas, 2006; Woolley, Tullos, 2009). With age, children gain experiences which help prevent fantasy-reality confusion (Cook, Sobel, 2011) and they become better able to use the knowledge they have about the real world to reject the possibility of fantastic events occurring in real life (Woolley, 1997). Second, children's reality status evaluations were regarded as likely to vary based on the emotional content of presented stimuli (e.g., Carrick, Quas, 2006; Samuels, Taylor, 1994). As previous research suggests, children are prone to state that positive events can occur in real life and negative events cannot. This might be due to the approach/avoidance mechanisms, emotion regulation strategies and children's wishes (Carrick, Quas, 2006). Third, there was a relationship postulated between children's wishes and their reality status judgments. As mentioned before, it is possible that children's reality status judgments reflect their wishes for positive events to occur in real life and for negative events not to occur in real life. Finally, there is a noticeable lack of research comparing children's reality status evaluations of events versus characters. Whilst fantasyreality confusion might be especially prevalent when children are asked to categorize events instead of single objects (Samuels, Taylor, 1994), there is no evidence to suggest differences in variation pattern of reality status judgments based on emotional content of presented stimuli for pictures depicting events and pictures depicting entities. We, therefore, postulated that said variation pattern would be similar for events and figures.

\section{METHOD}

\section{Participants}

The research was conducted on a sample of 71 Slovenian preschoolers ( 35 girls and 36 boys): 21 three-year-olds (mean age 3.6, ranging from 2.11 to 3.11 ), 25 four-year-olds (mean age 4.6, ranging from 4.0 to 4.11 ) and 25 five-year-olds (mean age 5.6, ranging from 5.0 to 5.11). The sample was drawn from two Slovenian kindergartens, one of which was set in an urban $(n=27)$ and the other in a rural environment $(n=44)$. The consent forms were signed by parents of all participants. All children were tested by the same researcher.

\section{Materials}

For the fantasy-reality differentiation interview, 32 illustrations from children's books available at the local library and cartoons currently playing on television were chosen based on a pilot study. Eight illustrations represented each of the following categories: real figures (e.g., a girl), fantasy figures (e.g., a witch), real events (e.g., a fox trying to catch a bird), and fantasy events (e.g., mice helping the cook). In the case of figures, all the illustrations' background was changed with the help of a computer program so that each of the images depicted a single figure on a plain white background. Within each of the four categories, two illustrations represented each of the following emotional states: neutral (e.g., a boy guarding the sheep), happiness (e.g., a happy chicken riding a surfboard), fear (e.g., a frightening 
lion) and anger (e.g., an angry duck). All the illustrations were in full color. The illustrations were printed to an A5 format.

A face scale was also used while conducting the interview. It consisted of five faces ranging from a large frowning face to a large happy face and was used to assess how the illustrations made children feel. That is, while viewing each image children were asked to point to the face that showed how that image made them feel (very badly, badly, ok, well, very well).

\section{Procedure}

Children were tested individually in the preschool they attended. Prior to testing, their verbal assent was secured as well as a written consent from their parents. The sessions began with the researcher presenting the children with the face scale and making sure they understood which face corresponded with which feeling. This was achieved by asking the children to point for example to "the face that feels very well" and then to "the face that feels badly". Next, the researcher began with the interview. The pictures were selected from the pile in random order (with the exception that the last image was positive to alleviate any negative reactions elicited by the fearful or angry images) and for each picture four questions were posed to the children. "What's on the picture?" was asked in order to direct the children's attention to the presented stimuli. Next "Is this picture good or bad?" was asked in conjunction with the face scale with the intention of judging the intensity of the children's emotional reactions, and the question “Can this happen in real life?" was asked to test the children's fantasy-reality distinction. Finally, "Do you want this to happen in real life?" was asked to explore the children's wishes. No corrections were made on the children's answers regarding the images.

Children's answers on the face scale were scored on a 5-point scale based on the face to which the child pointed (from $1=$ very bad to $5=$ very good). Mean scores were calculated for each emotion (neutral, happy, sad and angry). Lower scores indicate more negative reactions while higher scores indicate more positive reactions. Children's answers to the question "Can this happen in real life?" were scored 0 if the child's reality status judgment was incorrect and 1 if their reality status judgment was correct. While their responses to the question "Do you want this to happen in real life?" were scored 0 if the child's response was negative and 1 if their response was positive.

\section{RESULTS}

This section of the paper starts with preliminary analyses, after which the children's fantasy-reality distinction scores across different types of stimuli are presented. The presentation of results concludes with an examination of correlation between the children's wishes and their reality-status judgments.

\section{Preliminary Analyses}

First, to identify gender and residential (i.e., urban/rural) differences in the children's responses, an independent t-test was conducted across the main study variables: age, mean fantasy-reality distinction scores, mean wish scores and mean emotional ratings. No significant differences emerged, thus both gender and place of residence were excluded from further analyses. 
Second, to analyze the children's emotional ratings of presented stimuli, repeated measures ANOVA was conducted on the children's emotional ratings of four types of stimuli (neutral, happy, angry, scary). The results show a significant variation of responses across emotional content of presented stimuli, $\mathrm{F}(3,204)=376.47, \mathrm{p}=0.00$. Children rated happy images $(\mathrm{M}=4.54)$ as more positive than they did neutral $(\mathrm{M}=$ $3.23)$, frightening $(M=1.95)$, or angry $(M=$ 2.18) images. Mean rating of neutral images differed significantly from $3, \mathrm{t}(70)=3.03, \mathrm{p}=$ 0.00 , meaning children's reactions to neutral images were slightly positive.

Third, to assess age differences in fantasyreality distinction scores, one-way independent ANOVA was used. A significant agerelated improvement in fantasy-reality distinction emerged, $\mathrm{M}_{3 \mathrm{yr}}=17.95, \mathrm{M}_{4 y r}=19.48$, $\mathrm{M}_{5 y r}=21.32, \mathrm{~F}(2,68)=7.67, \mathrm{p}=0.00$. Based on a priori contrasts 3 -year-olds achieved significantly lower fantasy-reality distinction scores than 4- and 5-year-old, $\mathrm{t}(68)=3.33$, $\mathrm{p}=0.00, \mathrm{r}=0.37$, whereas 5-year-olds' scores were significantly higher than those of 4-year-olds, $\mathrm{t}(68)=2.07, \mathrm{p}=0.04, \mathrm{r}=0.24$.

\section{Children's Fantasy-Reality Distinction Scores across Different Types of Stimuli}

First, to assess the children's fantasyreality scores across different types of stimuli, repeated measures ANOVA was conducted. A significant difference in proportion of the children's correct responses across different types of emotional content of the stimuli emerged, $\mathrm{F}(3,204)=15.87$, $\mathrm{p}=0.00$. Whilst there was no significant difference in proportions of the children's correct evaluations of neutral and happy stimuli, $\mathrm{F}(1,68)=1.05, \mathrm{p}=0.31$, simple contrasts showed that the children's fantasyreality distinctions were correct significantly more often in neutral condition than when presented with scary, $\mathrm{F}(1,68)=15.85, \mathrm{p}=$ $0.00, \mathrm{r}=0.43$, or angry stimuli, $\mathrm{F}(1,68)=$ $41.335, \mathrm{p}=0.00, \mathrm{r}=0.61$. The interaction between age and emotional content of the stimuli was not significant, $F(6,204)=1.88$, $\mathrm{p}=0.84$, suggesting that the children's fantasy-reality distinctions were affected by the emotional content of presented stimuli regardless of their age.

Second, to explore how children's responses vary based on emotional content of presented stimuli, the procedure was repeated only on images depicting real motifs. When only images depicting real figures were considered, children provided significantly greater proportion of correct responses for the neutral and happy stimuli than for frightening and angry stimuli, $\mathrm{F}(3,204)=52.29, \mathrm{p}=0.00$. This pattern was repeated when only images depicting real events were considered, $\mathrm{F}(3,204)=131.00$, $\mathrm{p}=0.00$. As expected, the opposite pattern of correct responses emerged when considering only images depicting fantastic events and figures. In this instance, children provided a significantly higher proportion of correct fantasy-reality distinctions for frightening and anger-related events, $\mathrm{F}(2.73,185.82)=41.74, \mathrm{p}=0.00$, and figures, $\mathrm{F}(3,204)=33.34, \mathrm{p}=0.00$, than for neutral and happy events and figures.

Results showed a significant difference in fantasy-reality distinction scores between images depicting events and images depicting figures, $F(1,68)=10.59, \mathrm{p}=0.00$, suggesting that the children were better able to distinguish real and fantastic events than real and fantastic figures. 
Table 1. Means and standard deviations of fantasy-reality scores across types of stimuli

\begin{tabular}{|l|l|l|l|l|l|l|l|l|}
\hline \multirow{2}{*}{ Type of stimuli } & \multicolumn{2}{|c|}{ 3-year-olds } & \multicolumn{2}{|c|}{ 4-year-olds } & \multicolumn{2}{c|}{ 5-year-olds } & \multicolumn{2}{|c|}{ Mean } \\
\cline { 2 - 9 } & $\mathrm{M}$ & $\mathrm{SD}$ & $\mathrm{M}$ & $\mathrm{SD}$ & $\mathrm{M}$ & $\mathrm{SD}$ & $\mathrm{M}$ & $\mathrm{SD}$ \\
\hline Real figures & & & & & & & & \\
\hline Neutral & 0.64 & 0.09 & 0.52 & 0.06 & 0.36 & 0.07 & $0.50^{\mathrm{a}}$ & 0.37 \\
\hline Happy & 0.83 & 0.06 & 0.88 & 0.04 & 0.70 & 0.07 & 0.80 & 0.30 \\
\hline Scary & 0.28 & 0.07 & 0.22 & 0.05 & 0.24 & 0.07 & 0.24 & 0.32 \\
\hline Angry & 0.35 & 0.08 & 0.30 & 0.08 & 0.32 & 0.08 & 0.32 & 0.38 \\
\hline M & $0.52^{\mathrm{c}}$ & 0.06 & $0.48^{\mathrm{c}}$ & 0.04 & $0.41^{\mathrm{c}}$ & 0.05 & 0.47 & 0.24 \\
\hline Fantastic figures & & & & & & & & \\
\hline Neutral & 0.52 & 0.10 & 0.74 & 0.07 & 0.84 & 0.06 & $0.71^{\mathrm{a}}$ & 0.39 \\
\hline Happy & 0.21 & 0.08 & 0.42 & 0.09 & 0.64 & 0.07 & $0.43^{\mathrm{b}}$ & 0.43 \\
\hline Scary & 0.78 & 0.06 & 0.88 & 0.05 & 0.98 & 0.02 & $0.88^{\mathrm{a}}$ & 0.24 \\
\hline Angry & 0.71 & 0.08 & 0.80 & 0.06 & 0.84 & 0.06 & 0.79 & 0.32 \\
\hline M & $0.56^{\mathrm{c}}$ & 0.06 & $0.71^{\mathrm{c}}$ & 0.04 & $0.82^{\mathrm{c}}$ & 0.04 & 0.71 & 0.25 \\
\hline Real events & & & & & & & & \\
\hline Neutral & 0.81 & 0.06 & 0.86 & 0.05 & 0.78 & 0.06 & 0.82 & 0.30 \\
\hline Happy & 0.88 & 0.06 & 0.98 & 0.02 & 0.84 & 0.06 & 0.90 & 0.25 \\
\hline Scary & 0.21 & 0.06 & 0.24 & 0.07 & 0.38 & 0.08 & 0.28 & 0.36 \\
\hline Angry & 0.19 & 0.05 & 0.18 & 0.06 & 0.20 & 0.07 & 0.19 & 0.31 \\
\hline M & $0.52^{\mathrm{c}}$ & 0.04 & $0.56^{\mathrm{c}}$ & 0.03 & $0.55^{\mathrm{c}}$ & 0.05 & 0.55 & 0.20 \\
\hline Fantastic events & & & & & & & & \\
\hline Neutral & 0.54 & 0.09 & 0.60 & 0.09 & 0.88 & 0.05 & $0.68^{\mathrm{b}}$ & 0.40 \\
\hline Happy & 0.23 & 0.07 & 0.34 & 0.08 & 0.84 & 0.06 & $0.48^{\mathrm{b}}$ & 0.45 \\
\hline Scary & 0.95 & 0.03 & 0.92 & 0.04 & 0.94 & 0.03 & 0.94 & 0.17 \\
\hline Angry & 0.78 & 0.07 & 0.86 & 0.06 & 0.88 & 0.05 & 0.84 & 0.30 \\
\hline M & $0.63^{\mathrm{c}}$ & 0.05 & $0.68^{\mathrm{c}}$ & 0.05 & 0.88 & 0.03 & 0.74 & 0.24 \\
\hline Grand M & $0.56^{\mathrm{c}}$ & 0.01 & $0.60^{\mathrm{c}}$ & 0.02 & $0.66^{\mathrm{c}}$ & 0.02 & $0.61^{\mathrm{bc}}$ & 0.10 \\
\hline Note: & & & & & & & \\
\hline
\end{tabular}

Note: Higher scores indicate a greater proportion of correct responses. Superscripts

${ }^{\mathrm{a}}$ and ${ }^{\mathrm{b}}$ indicate significant age differences at 0.05 and 0.01 level respectively.

Superscript ${ }^{c}$ indicates significant differences among types of stimuli at 0.01 level.

\section{Children's Wishes}

To assess the children's wish scores across different types of stimuli, repeated measures ANOVA was conducted. The children's wish scores were significantly higher for happy events and figures and lower for frightening and angry events and figures, $\mathrm{F}(2.65,180.27)=226.96, \mathrm{p}=0.00$. The children stated that they wished neutral and happy events would occur in real life and that frightening and angry events would not occur in real life. As seen in Table 2, the children's wish scores were positively correlated with their reality status responses 
Table 2. Mean wish scores and correlations between children's reality status responses and wish scores.

\begin{tabular}{|l|c|c|c|c|}
\hline \multirow{2}{*}{} & \multicolumn{4}{|c|}{ Emotional content of presented stimuli } \\
\cline { 2 - 5 } & neutral & happy & frightening & angry \\
\hline $\mathrm{M}$ & 0.58 & 0.81 & 0.17 & 0.23 \\
\hline $\mathrm{R}$ & 0.78 & 0.73 & 0.52 & 0.70 \\
\hline
\end{tabular}

Note. Higher mean wish score indicates a greater desire for the events and figures to happen in real life. All correlations are significant at 0.01 level.

across all four emotions. Furthermore, regression analysis showed that the children's wishes explained a significant proportion of variance in fantasy-reality distinction scores, $\mathrm{R}^{2}=0.70, \mathrm{~F}(1,290)=693.98, \mathrm{p}=0.00$.

\section{DISCUSSION}

Preschool years are a period of great cognitive, emotional, and social change. The evidence against the old assumption that the early childhood is a time of inability to distinguish between fantasy and reality is increasing. There seem to be many factors influencing children's fantasy-reality distinctions. The present article focused on four: age differences, emotional content of presented stimuli, children's wishes and children's fantasy-reality distinction of figures versus events. The central goal of this study was to examine the association between emotional content of presented stimuli and children's ability to distinguish between real and fantastic events and figures. Furthermore, we examined the possibility of an association between children's reality status assessments and their wishes. Finally, we explored the relationship between children's fantasy-reality distinction scores and type of presented stimuli (figures vs. events).
Several hypotheses were postulated based on results from previous studies. First, agerelated improvement in children's fantasyreality distinction was expected. The results confirmed that older children were indeed better able to distinguish fantastic events and figures from real events and figures. These results were expected not only because of a significant increase in the amount of knowledge children possess about the fantasy-reality boundary (Phelps, Woolley, 1994), but also because of their increasing ability to use that knowledge to determine the reality status of presented stimuli (Woolley, 1997). This might be due to the increases in memory capacity and speed of information processing (Siegler, 1997) and of systematic attention development (Marjanovič Umek, 2004). Early childhood is also a period, when there are significant increases in children's ability to use context (Woolley, Van Reet, 2006) and physical evidence (Tullos, Woolley, 2009) to infer reality-status judgments, in their ability to dismiss the possibility of an imaginary entity existing in reality and to perceive consistency of beliefs (Woolley, 1997), and in their ability to distinguish between impossible and improbable events (Shtulman, Carey, 2007). This is also a time of significant advancement in verbal skills (Deák, Ray, Brenneman, 
2003). All these changes might lead to a decrease in children's uncertainty when it comes to fantasy-reality boundary (Woolley, 1997) and an increase in their ability to distinguish between the two worlds. The results from current study support this idea, as the average percentage of correct reality-status assessments was $56 \%$ for the 3 -year-olds, $61 \%$ for the 4 -year-olds and $66 \%$ for the 5 year-olds.

Second, the children's reality status evaluations were regarded as likely to vary based on emotional content of presented stimuli. As expected, the results showed children were prone to report that happy events and figures could appear in real life and that frightening and angry events and figures could not occur in real life regardless of the actual reality-status of the presented stimuli. These results are in accordance with those of previous studies (e.g., Carrick, Quas, 2006; Carrick et al., 2010; Samuels, Taylor, 1994). In their study, Carrick and Quas (2006) proposed that motivational processes underlie children's fantasy-reality judgments. These motivational processes are said to be approach/avoidance tendencies and emotion regulation strategies. It has been proposed that when facing frightening stimuli, children use the answer to the question Can X happen in real life? in an attempt to regulate their arousal. That is, claiming frightening stimuli could not happen in real life could be seen as an attempt at dealing with the negative emotional reaction to the image (Samuels, Taylor, 1997). Based on results of the present study, the same could be true when dealing with angry stimuli. As expected, avoidance tendencies appeared when children were presented with frightening or angry images and children were prone to state that both fantastic and real stimuli could not happen in real life. Similar mechanisms were probably at work when faced with happy images. In this case, children might have used the answer to the previously mentioned question as a way of reinforcing their positive emotions (Carrick, Quas, 2006). When children were presented with images with happy content, the approach tendencies came into effect and children stated that both fantastic and real stimuli could happen in real life. The results also support the assumption that competence in fantasy-reality distinction is associated with neutral stimuli, a notion that has already been proposed by several previous studies (Bourchier, Davis, 2002; Carrick, Quas, 2006; Samuels, Taylor, 1997).

Another motivational process that was examined in the present study was children's wishes. A relationship between children's wishes and their reality status judgments was postulated prior to the research. This expectation was based on the proposal of several authors, regarding the possibility of preschoolers' reality status judgments reflecting their wishes for certain events to occur in real life rather than their actual understanding (Carrick, Quas, 2006; Woolley, 1997). The results were consistent with our expectations in that we found a significant positive correlation between the children's reality status responses and their wish scores. That is, the children were prone to stating that the stimuli they wished would occur in real life could indeed occur in real life. There are, however, two notable limitations to the method used in collecting data about children's wishes. First, it does not enable us to draw any causal conclusions. And second, it did not eliminate the possibility of perseveration error. In their study, Deák et al. (2003) warn that perseveration error is a common occurrence when children between the ages of three and 
five are asked to give two or more verbal forced choice answers to a complex stimuli. This error could in fact inflate correlation coefficients between children's wish scores and their fantasy-reality distinction scores. Future research is needed to determine the extent and causality of the relationship.

Finally, the variation pattern of reality status judgments, based on emotional content of presented stimuli, was expected to be similar for pictures depicting events and pictures depicting figures. The results confirmed this expectation. Children were prone to stating that positively valenced events could and negatively valenced events could not occur in real life - a pattern that was repeated when only images depicting figures were considered. An interesting possibility emerged, when we compared the proportion of correct reality status evaluations for events and figures: children were better able to distinguish real and fantastic events than real and fantastic figures, suggesting that the presence of local context plays a role in children's ability to discern fantasy and reality. Local context - present in the images depicting events - might help children distinguish between fantasy and reality by enhancing the contrast between what is real and what is not, and by drawing their attention to the criteria used to separate these two worlds. Further research is needed to explore this possibility.

In closing, research focusing on fantasyreality distinction in early childhood is vital to our understanding of children's functioning in many aspects of their lives. For example, findings from this field of research can be used to shape curriculums in preschools and improve validity of forensic interviewing of children. Furthermore, it can be utilized to form ethical and legal guide- lines to regulate child oriented advertising. Finally, because early theory of mind is related to peer acceptance in later years (Caputi et al., 2012), the research on children's fantasy-reality distinction can be used to build and subsequently implement early peer-rejection prevention programs.

The present study shed new light on preschoolers' fantasy-reality distinction by enabling a direct comparison of children's responses, not only across several discrete emotions but also across different types of presented stimuli (i.e., events vs. figures). Furthermore, we were able to test the hypothesis that children's reality status judgments relate to their desires. The results we gained are consistent with the conclusion of Carrick and Quas (2006), which is, that at least some of the difficulties children experience when trying to distinguish between real and fantastic emotional stimuli are due more to the motivational factors than to children's actual understanding. Further research is needed to test the role of local context in children's ability to distinguish fantasy and reality as well as to test the extent and nature of the relationship between said ability and children's wishes.

Received October 26, 2013

\section{REFERENCES}

BOERGER, E.A., 2011, 'In fairy tales fairies can disappear': Children's reasoning about the characteristics of humans and fantasy figures. British Journal of Developmental Psychology, 29, 635-655.

BOURCHIER, A., DAVIS, A., 2000a, Individual and developmental differences in children's understanding of the fantasy-reality distinction. British Journal of Developmental Psychology, 18, 353368 .

BOURCHIER, A., DAVIS, A., 2000b, The influence of availability and affect on children's under- 
standing of the fantasy-reality distinction. British Journal of Developmental Psychology, 18, 137 156 .

BOURCHIER, A., DAVIS, A., 2002, Children's understanding of the pretence-reality distinction: A review of current theory and evidence. Developmental Science, 5, 397-426.

CAPUTI, M., LECCE, S., PAGNIN, A., BANERJEE, R., 2012, Longitudinal effects of theory of mind on later peer relations: The role of prosocial behaviour. Developmental Psychology, 48, 257-270.

CARRICK, N., QUAS, J., 2006, Effects of discrete emotions on young children's ability to discern fantasy and reality. Developmental Psychology, 42, 1278-1288.

CARRICK, N., QUAS, J., LYON, T., 2010, Maltreated and nonmaltreated children's evaluations of emotional fantasy. Child Abuse and Neglect, 34, 129-134.

CARVER, C.S., WHITE, T.L., 1994, Behavioral inhibition, behavioral activation, and affective responses to impending reward and punishment: The BIS/BAS Scales. Journal of Personality and Social Psychology, 67, 319-333.

COOK, C., SOBEL, D.M., 2011, Children's beliefs about the fantasy/reality status of hypothesized machines. Developmental Science, 14, 1-8.

DEÁK, G.O., RAY, S.D., BRENNEMAN, K., 2003, Children's perseverative appearance-reality errors are related to emerging language skills. Child Development, 74, 944-964.

GOLOMB, C., GALASSO, L., 1995, Make believe and reality: Explorations of the imaginary realm. Developmental Psychology, 31, 800810 .

HARRIS, P.L., BROWN, E., MARRIOTT, C., WHITTALL, S., HARMER, S., 1991, Monsters, ghosts and witches: Testing the limits of the fantasy-reality distinction in young children. British Journal of Developmental Psychology, 9, 105123.

MARJANOVIČ UMEK, L., 2004, Spoznavni razvoj v zgodnjem otroštvu [Cognitive development in early childhood]. In: L. Marjanovič Umek, M. Zupančič (Eds.), Razvojna psihologija [Developmental psychology] (pp. 291-314). Ljubljana: Znanstvenoraziskovalni Inštitut Filozofske Fakultete.
MORISON, P., GARDNER, H., 1978, Dragons and dinosaurs: The child's capacity to differentiate fantasy from reality. Child Development, 49, 642648.

PHELPS, K.E., WOOLLEY, J.D., 1994, The form and function of young children's magical beliefs. Developmental Psychology, 30, 385-394.

SAMUELS, A., TAYLOR, M., 1994, Children's ability to distinguish fantasy events from real life events. British Journal of Developmental Psychology, 12, 417-427.

SAYFAN, L., HANSEN LAGATTUTA, K., 2009, Scaring the monster away: What children know about managing fears of real and imaginary creatures. Child Development, 80, 1756-1774.

SHARON, T., WOOLLEY, J.D., 2004, Do monsters dream? Young children's understanding of the fantasy/reality distinction. British Journal of Developmental Psychology, 22, 293-310.

SIEGLER, R.S., 1997, Children's thinking. New Jersey: Prentice Hall.

WACKER, J., HELDMANN, M., STEMMLER, G., 2003, Separating emotion and motivational direction in fear and anger: Effects on frontal asymmetry. Emotion, 3, 167-193.

WEISBERG, D.S., SOBEL, D.M., 2012, Young children discriminate improbable from impossible events in fiction. Cognitive Development, 27, 9098.

WOOLLEY, J.D., 1997, Thinking about fantasy: Are children fundamentally different thinkers and believers from adults? Child Development, 68, 9911011

WOOLLEY, J.D., PHELPS, K.E., DAVIS, D.L., MANDELL, D.J., 1999, Where theories of mind meet magic: The development of children's beliefs about wishing. Child Development, 70, 571-587.

WOOLLEY, J.D., TULLOS, A., 2009, Imagination and fantasy. In: J.B. Benson, M.M. Haith (Eds.), Language, memory, and cognition in infancy and early childhood (pp. 237-246). Oxford: Academic Press.

WOOLLEY, J.D., VAN REET, J., 2006, Effects of context on judgments concerning the reality status of novel entities. Child Development, 77, 17781793

WOOLLEY, J.D., WELLMAN, H.M., 1992, Children's conceptions of dreams. Cognitive Development, 7, 365-380. 


\title{
ŠŤASTNÝ DRAK JE SKUTOČNÝ, DESIVÝ DRAK NIE JE: ROZLIŚSENIE EMOČNÝCH PODNETOV V REALITE A FANTÁZII U DETÍ
}

\author{
S. Metli č a r
}

Súhrn: Štúdia sa zmeriava na rozlíšenie medzi realitou a fantáziou u emočných podnetov v ranom detstve. Skúmalo sa niekol'ko faktorov, vrátane vekových rozdielov, želaní detí, a kontextu prostredia. Výskumnú vzorku tvorilo 71 detí vo veku $3-5$ rokov. Det’om sme ukázali obrázky znázorňujúce fantastické a skutočné udalosti a postavy, ktoré vyvolali viacero emócie. Deti potom uvádzali, či sa daná udalost' alebo postava môže objavit' v skutočnom živote, uvádzali svoje želania týkajúce sa výskytu danej udalosti v skutočnosti a hodnotili svoju emočnú reakciu na obrázok. Výsledky ukázali zlepšenia v rozlišovaní medzi realitou a fantáziou u emočných podnetov spájajúce sa s vekom a pozitívne korelácie medzi hodnotením reality a želaniami u detí, ako aj variácie v usudzovaní založenom na emočnom obsahu prezentovaných podnetov. Deti mali sklon uvádzat', že neutrálne a št’astné podnety sú možné aj v skutočnosti a desivé a zlostné podnety sa v skutočnosti nemôžu vyskytnút'. 